\title{
Characterization and adsorption of Lactobacillus virulent phage P1
}

\author{
X. Chen, ${ }^{1}$ Y. Xi, H. Zhang, Z. Wang, M. Fan, Y. Liu, and W. Wu \\ Key Laboratory of Dairy Biotechnology and Engineering, Ministry of Education, Inner Mongolia Agricultural University, Huhhot, \\ 010018, P. R. China
}

\section{ABSTRACT}

Bacteriophage infection of lactic acid bacteria is considered an important problem worldwide in the food fermentation industry, as it may produce low quality or unsafe foods, cause fermentation failure, and result in economic losses. To increase current knowledge on the properties of Lactobacillus virulent phages, we evaluated the effect of divalent cations, temperature, $\mathrm{pH}$, and chloramphenicol on the adsorption ability of Lactobacillus virulent phage P1. Phage P1 was isolated from the abnormal fermentation liquid of Lactobacillus plantarum IMAU10120. The results showed that this phage belonged to the Siphoviridae family. The latent period of this phage was $45 \mathrm{~min}$, and the burst time was 90 min. Burst size was $132.88 \pm 2.37$ phage counts expressed per milliliter per infective center. This phage showed good tolerance at different temperatures, but incubation at $50^{\circ} \mathrm{C}$ only affected its adsorption. Adsorption rate reached a maximum value between 30 and $42^{\circ} \mathrm{C}$. A high adsorption value of phage infectivity was obtained from $\mathrm{pH} 6$ to 8 . Moreover, calcium ions promoted and increased the adsorption capacity of phage $\mathrm{P} 1$, but magnesium ions had negative effects. Chloramphenicol had no effect on phage adsorption. This study increased current knowledge on the characterization and biological aspects of Lactobacillus virulent phages, and may provide some basic information that can be used to design successful antiphage strategies in the food industry.

Key words: Lactobacillus virulent phage, tolerance, adsorption, burst size

\section{INTRODUCTION}

Lactobacillus plantarum is a flexible and versatile species that grows in diverse environment niches, such

\footnotetext{
Received April 19, 2016.

Accepted May 25, 2016.

${ }^{1}$ Corresponding author: chenxia8280@163.com
}

as fermented food products, meat, and plant materials (Ma et al., 2016), and it is frequently considered a natural inhabitant of the human gastrointestinal tract (Costa et al., 2014). It has been used in human clinical trials to promote a beneficial effect on the immune system, to alleviate intestinal disorders, and to reduce the risk of cardiovascular disease. It is also involved in many fermentation processes in the food industry and to improve the organoleptic characteristics of the final products (Costa et al., 2014).

However, the increasing use of $L$. plantarum as a starter or adjunct culture may increase the chances of phage infections in industrial environment, with adverse effects on the final products (Briggiler Marcó et al., 2012). Contamination with bacteriophage is currently considered one of the greatest problems in food fermentation industry worldwide, especially in dairy fermentation. In the modern food industry, the disruption of lactic acid fermentation by bacteriophages can lead to slow or substandard dairy fermentation. Moreover, virulent phages can lyse starter cultures, yielding lowquality products, and then lead to economic losses for the producer. Consequently, efficient control measures to minimize problems caused by phage attacks are essential. Thus, knowledge about phage population and biology is necessary to carry out successful antiphage strategies (Kodaira et al., 1997; Emond and Moineau, 2007).

Adsorption to the host cell surface is considered the first step of phage infection, and it has been studied for several species of lactic acid bacteria (Capra et al., 2006; Müller-Merbach et al., 2007; Suárez et al., 2008; Briggiler Marcó et al., 2010). To our knowledge, information related to phages infected on L. plantarum is very limited. Lactobacillus plantarum IMAU10120 was isolated from traditional fermented yogurt in Inner Mongolia, China. This strain exhibited several desirable properties, including high acid and bile tolerance, good aggregation and antibacterial activities, as well as high soy milk fermentation efficiency and strong stability upon storage. Virulent phage P1 was isolated from the fermented liquid of $L$. plantarum IMAU10120 lacking significant viable counts. The purpose of the 
current work was to analyze the characteristics of $L$. plantarum phage $\mathrm{P} 1$ and evaluate the interaction of this phage with its host strain, especially the influence of physicochemical parameters on phage adsorption to sensitive cells.

\section{MATERIALS AND METHODS}

\section{Bacterial Strains, Phages, and Culture Condition}

Lactobacillus plantarum IMAU10120 was grown at $37^{\circ} \mathrm{C}$ in de Man, Rogosa, and Sharpe (MRS) broth (Difco, Becton Dickinson and Company, Franklin Lakes, NJ) and used as the host strain for phage P1. Lactobacillus plantarum phage $\mathrm{P} 1$ was isolated from the abnormal fermented liquid of L. plantarum IMAU10120. For phage amplification, MRS was supplemented with $10 \mathrm{mM} \mathrm{CaCl}_{2}$. Phage stocks were prepared as described previously (Neviani et al., 1992) and stored as lysates at $4^{\circ} \mathrm{C}$. Phage counts expressed in plaque-forming units (pfu) per milliliter were obtained using the doublelayer plaque titration method (Quiberoni et al., 2011). The bacterial strain was obtained from the Lactic Acid Bacteria Collection Center in the Key Laboratory of Dairy Biotechnology and Engineering, Ministry of Education, Inner Mongolia Agricultural University.

\section{Electron Microscope}

Electron micrographs of phages were obtained according to De Antoni et al. (2010). Phage suspensions were concentrated by centrifugation $(1 \mathrm{~h}, 70,000 \times g$, $\left.5^{\circ} \mathrm{C}\right)$ and then stained using uranyl acetate $(2 \% \mathrm{wt} / \mathrm{vol}$, $\mathrm{pH} 4.5)$ or phosphotungstic acid (2\% wt/vol). Electron micrographs were taken with an JEOL H-7000 electron microscope (Jeol USA Inc., Peabody, MA) operating at $75 \mathrm{kV}$. Phage morphologies and dimensions (capsid diameter, tail length and width) were recorded.

\section{One-Step Growth Curve}

The host strain, L. plantarum IMAU10120, was grown to exponential growth (optical density at 600 $\mathrm{nm}=0.5)$ was harvested and suspended in $100 \mu \mathrm{L}$ of MRS-Ca broth. Phages were added at a multiplicity of infection (MOI) of 2. After adsorption (15 min at $37^{\circ} \mathrm{C}$ ), cells were harvested by centrifugation at 10,000 $\times g$ for 5 min at room temperature. Decimal dilutions of this suspension were carried out and incubated at $37^{\circ} \mathrm{C}$. At regular intervals $(15 \mathrm{~min}), 100 \mu \mathrm{L}$ of each dilution was collected for bacteriophage counts (Capra et al., 2006). Latent period, burst time, and burst size were calculated from one-step growth curve.

\section{Influence of Temperature on Phage and Strain Viability}

Phages $\left(10^{7} \mathrm{pfu} / \mathrm{mL}\right)$ or strain culture $\left(10^{8} \mathrm{cfu} / \mathrm{mL}\right)$ were suspended in MRS broth, placed into Eppendorf tubes ( $1 \mathrm{~mL}$ final volume), and incubated at $0,10,20$, $30,37,42$, and $50^{\circ} \mathrm{C}$ for $30 \mathrm{~min}$. The surviving phage particles or bacterial cells were immediately counted and the results were expressed as a percentage of remaining phage or cell counts to the initial phage or cell counts.

\section{Influence of $\mathrm{pH}$ on Phage and Strain Viability}

Phages $\left(10^{7} \mathrm{pfu} / \mathrm{mL}\right)$ or strain culture $\left(10^{8} \mathrm{cfu} / \mathrm{mL}\right)$ were suspended in MRS broth at various $\mathrm{pH}$ (from 2 to 11), placed into Eppendorf tubes ( $1 \mathrm{~mL}$ final volume) for $30 \mathrm{~min}$, and used to test the effect of $\mathrm{pH}$ on phage particles or bacterial cells, which were immediately plated and counted as described above. The results were expressed as a percentage of remaining phage or cell counts to the initial phage or cell counts.

\section{Influence of Temperature on Phage Adsorption}

The adsorption of phages on L. plantarum IMAU10120 was determined at $0,10,20,30,37,42$, and $50^{\circ} \mathrm{C}$. The infected $(\mathrm{MOI}=0.5)$ L. plantarum cultures in MRS broth were incubated at different temperatures for 45 min. Results were expressed as percentages of adsorption after $45 \mathrm{~min}$ and plotted against temperature values.

\section{Influence of $\mathrm{pH}$ on Phage Adsorption}

The influence of different $\mathrm{pH}$ values (from 2 to 11 ) on cell lysis was evaluated by incubating the infected $(\mathrm{MOI}=2)$ L. plantarum cultures in MRS broth at $37^{\circ} \mathrm{C}$ for $45 \mathrm{~min}$. The results were expressed as percentage of adsorption after $45 \mathrm{~min}$ and plotted against $\mathrm{pH}$ values.

\section{Influence of Divalent Cations on Phage Adsorption}

The influence of $\mathrm{Ca}^{2+}$ and $\mathrm{Mg}^{2+}$ on cell lysis was checked by incubating the infected $(\mathrm{MOI}=0.5)$ cells in MRS broth with and without $\mathrm{CaCl}_{2}$ or $\mathrm{MgCl}_{2}(10$ $\mathrm{mmol} / \mathrm{L}$ ) at $37^{\circ} \mathrm{C}$. At intervals $(5,15,30$, and $45 \mathrm{~min})$, tubes were removed and centrifuged $(10,000 \times g, 5 \mathrm{~min}$, at room temperature) to sediment the phage-adsorbed bacteria. Then, the supernatants were assayed for unadsorbed phages (double-layer plate titration), and the counts were compared with the titer of a control without cells. The results were expressed as percentages of adsorbed phage counts to the initial phage counts. 


\section{Influence of Cell Protein Synthesis Inhibitors on Phage Adsorption}

The minimum concentration of chloramphenicol needed to inhibit protein synthesis in L. plantarum IMAU10120 was determined as described by Briggiler Marcó et al. (2012). Results were expressed as percentages of adsorption after $45 \mathrm{~min}$ and plotted against chloramphenicol concentration.

\section{Statistical Analysis}

All data were analyzed using the Originpro software (8.6, Originlab, Originlab Corp., Northampton, MA). Experiments were replicated 3 times. Means were compared using the one-way ANOVA procedure in SPSS (version 20.0.0, IBM Corp., Armonk, NY) at $P<0.05$.

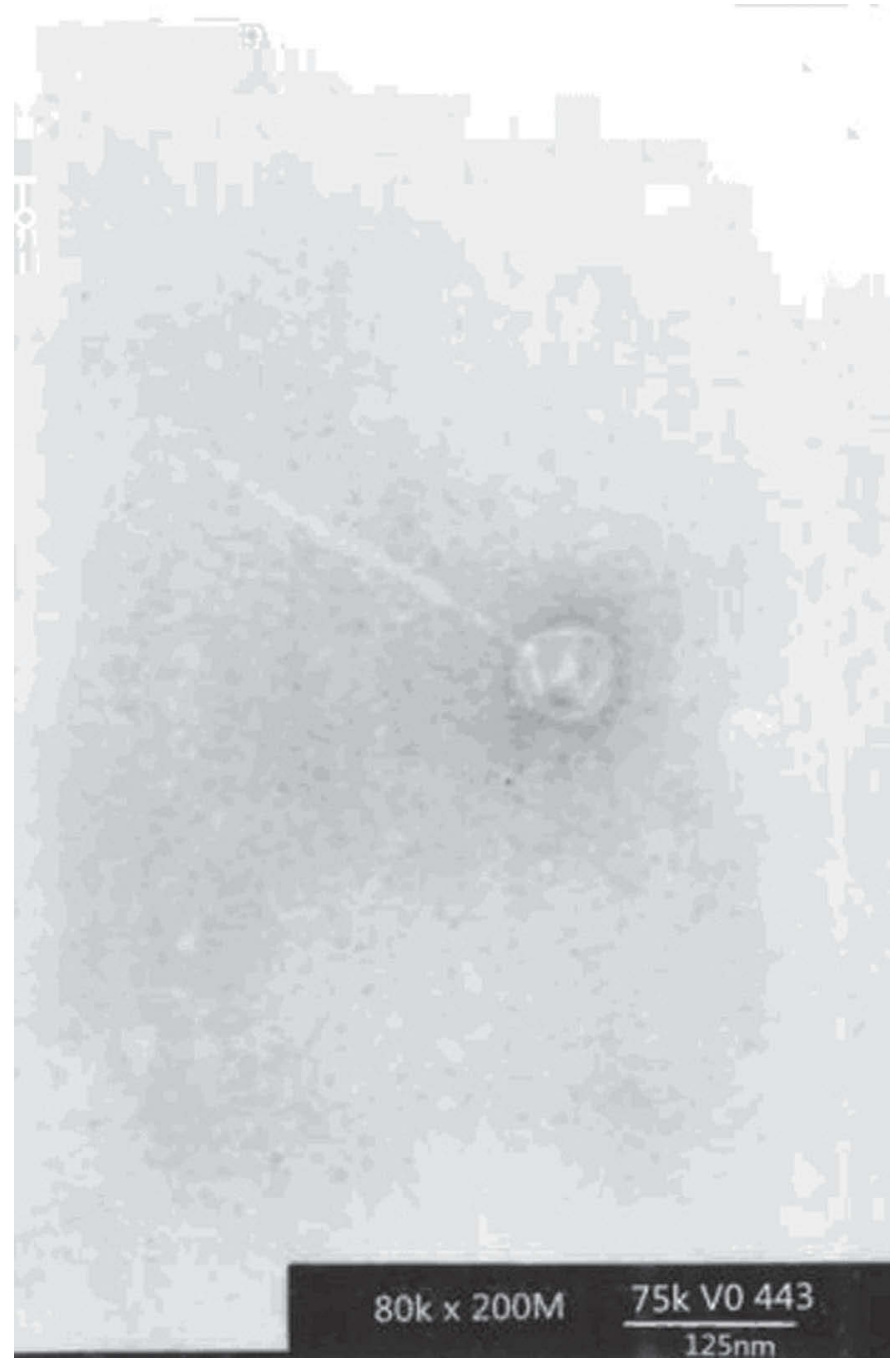
P1.

Figure 1. Electron micrograph of Lactobacillus plantarum phage

\section{RESULTS AND DISCUSSION}

\section{Electron Microscopy}

An electron micrograph of L. plantarum phage P1 is shown in Figure 1. The phage had an isometric capsid about $71.7 \pm 3.0 \mathrm{~nm}$ and a long noncontractile tail (about $272 \pm 3.0 \mathrm{~nm}$ long, $11.3 \pm 1.5 \mathrm{~nm}$ wide). Thus, based on morphology, it belonged to Siphoviridae family, as do most characterized L. plantarum phages (Villion and Moineau, 2009; Briggiler Marcó et al., 2012).

\section{One-Step Growth Curve}

Figure 2 shows the one-step growth curve of phage P1. As can be seen, the latent period of this phage was $45 \mathrm{~min}$ and the burst time was $90 \mathrm{~min}$. Burst size was $132.88 \pm 2.37 \mathrm{pfu} /$ infective center, which was higher than that of most Lactobacillus virulent phages (De Antoni et al., 2010; Briggiler Marcó et al., 2010).

\section{Influence of Temperature on Phage and Strain Viability}

From Figure 3a, we can conclude that the viability of phage suspensions was maintained, even at $50^{\circ} \mathrm{C}$. More than $95 \%$ of initial phage particles remained viable after 30 min of treatment in MRS broth. However, the viability of L. plantarum IMAU10120 was influenced by temperature. From Figure 3b, we can see that L. plantarum IMAU10120 grew well in a temperature range from 30 to $50^{\circ} \mathrm{C}$ but growth was slightly inhibited at temperatures $\leq 20^{\circ} \mathrm{C}$.

\section{Influence of $\mathrm{pH}$ on Phage and Strain Viability}

Unlike temperature, $\mathrm{pH}$ had a clear effect on phage infectivity (Figure 4a). High viability $(>90 \%)$ for P1 was observed in a $\mathrm{pH}$ range from 6 to 8 . The infectivity of viral suspensions was inactivated completely after 30 min at $\mathrm{pH} 2$ and almost completely (1.17\%) at $\mathrm{pH} 3$. This was in accordance with previous reports (Briggiler Marcó et al., 2010). As seen in Figure 4b, the viability of L. plantarum IMAU10120 was not influenced by $\mathrm{pH}$. At $\mathrm{pH} 2$, the viability of L. plantarum IMAU10120 reached $2.19 \times 10^{8} \mathrm{cfu} / \mathrm{mL}$.

\section{Influence of Temperature on Phage Adsorption}

Figure 5 shows the influence of temperature on phage adsorption. More than $85 \%$ of phage particles were adsorbed after 45 min at all temperatures tested except at $50^{\circ} \mathrm{C}$. Incubation at $50^{\circ} \mathrm{C}$ caused an increase in the per- 


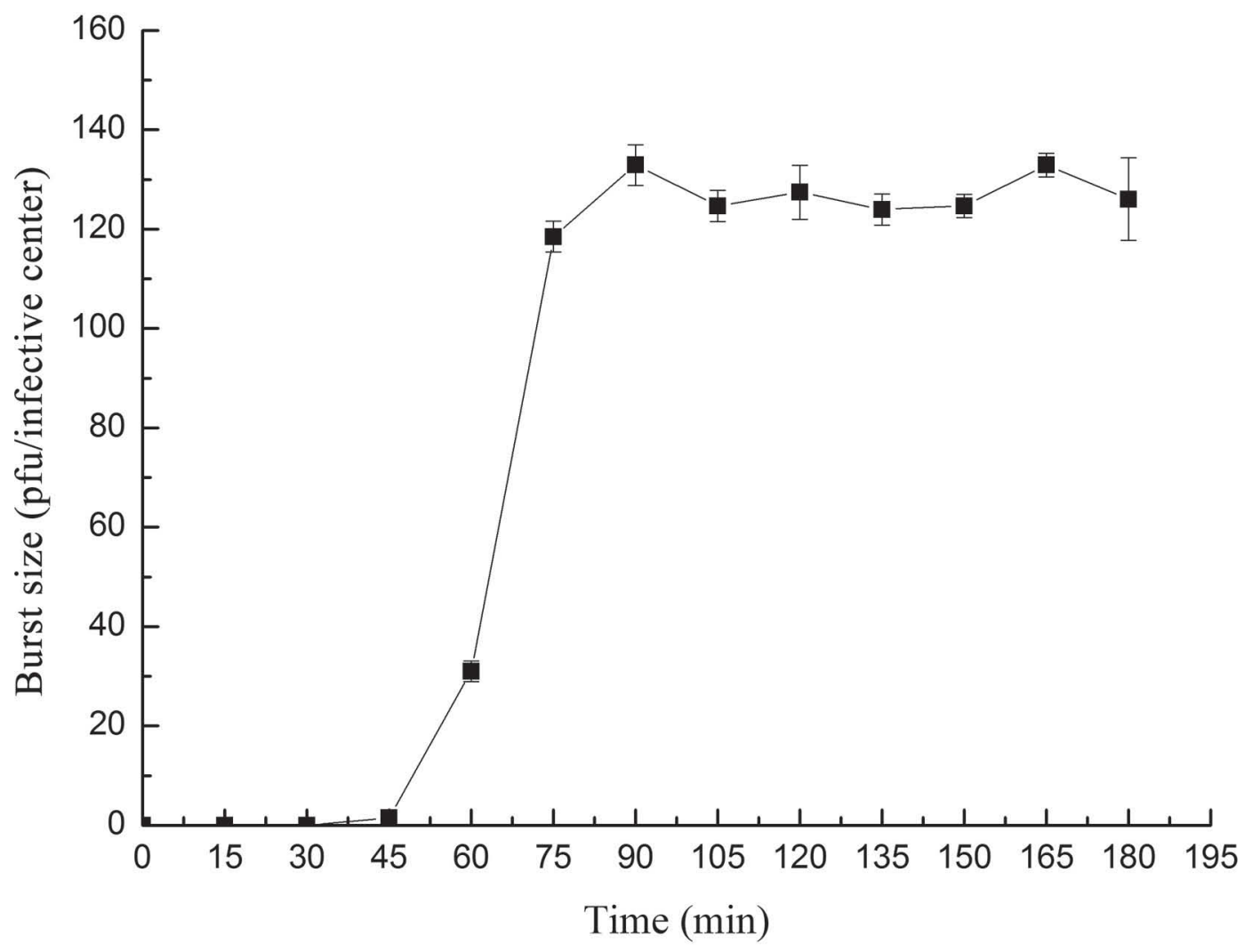

Figure 2. One-step growth curve of Lactobacillus plantarum phage P1. Values are the mean of 3 determinations. pfu $=$ plaque-forming units (phage counts). Error bars represent 95\% CI.

centage of unadsorbed phage particles (27.67\%). Maximum adsorption was achieved between 30 and $42^{\circ} \mathrm{C}$, which is similar to previous results (Briggiler Marcó et al., 2010); this may be because these temperatures are closer to the optimal temperature of growth for $L$. plantarum.

\section{Influence of $\mathrm{pH}$ on Phage Adsorption}

The influence of $\mathrm{pH}$ on phage adsorption is shown in Figure 6 . Between a $\mathrm{pH}$ of 4 to 8 , phage $\mathrm{P} 1$ showed a high rate of adsorption (more than 90\%) on the host strain, with the highest adsorption at $\mathrm{pH}$ 7. At $\mathrm{pH} 9$, the extent of adsorption was $50.00 \%$, and at $\mathrm{pH} 11$, adsorption decreased to $7.78 \%$.

\section{Influence of Divalent Cations on Phage Adsorption}

Cell lysis in MRS broth occurred even without divalent cations but it was faster in the presence of $\mathrm{Ca}^{2+}$ (Figure 7). Moreover, plaques (i.e., lysis) were very clear in the presence of $\mathrm{Ca}^{2+}$, whereas in the presence of $\mathrm{Mg}^{2+}$ or in the absence of cations, plaques were diffused or failed to clear.

\section{Influence of Cell Protein Synthesis Inhibitors on Phage Adsorption}

The chloramphenicol concentration used in the experiment was $20 \mu \mathrm{g} / \mathrm{mL}$; in that condition, the inhibition of protein synthesis in cells was maintained after removal of chloramphenicol. Thus, phage adsorption process was carried out without antibiotics. Treatment with chloramphenicol did not affect adsorption $(P>$ 0.05 ) on cells compared with untreated cells. After 45 min of incubation, more than $94.5 \%$ of initial phage particles were adsorbed on cells with or without chloramphenicol treatment (data not shown).

Lactobacillus plantarum phage P1 was isolated from the abnormal fermented liquid of $L$. plantarum IMAU10120, which was isolated from traditional fermented yogurt in Inner Mongolia, China. Electron microscopy showed an isometric capsid of $71.7 \pm 3.0$ $\mathrm{nm}$ and long noncontractile tails (about $272 \pm 3.0 \mathrm{~nm}$ long, $11.3 \pm 1.5 \mathrm{~nm}$ wide), and the phage was classified as a member of the Siphoviridae family, similar to most characterized L. plantarum phages. Yoon et al. (2011) isolated a Lactobacillus temperate phage Sha 1 from mitomycin C-induced lysate of $L$. plantarum from kimchi of a similar size (with an isometric head about $58 \times$ 

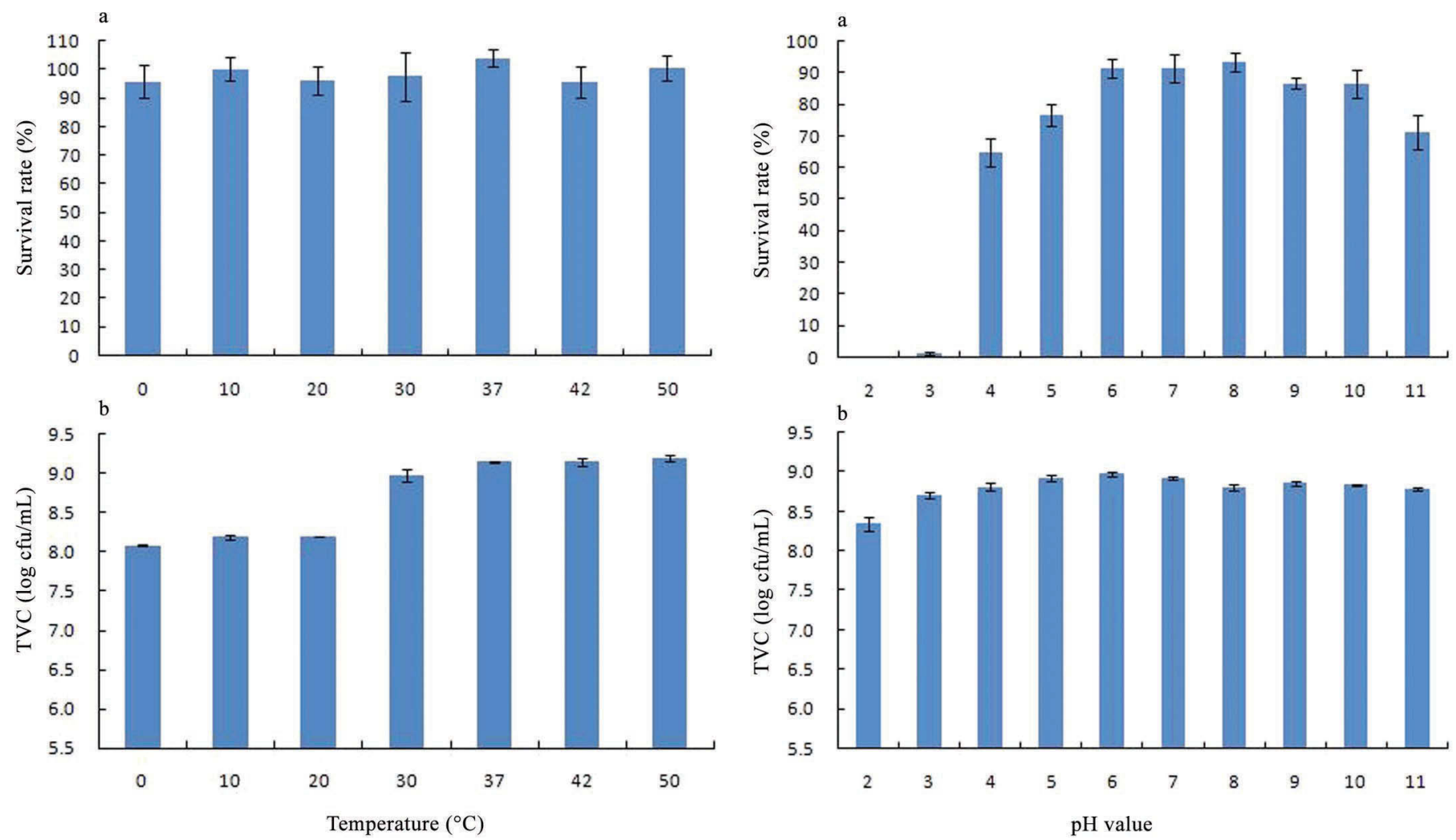

Figure 3. Influence of temperature on viability of (a) Lactobacillus plantarum phage $\mathrm{P} 1$, and (b) the host strain Lactobacillus plantarum IMAU10120 (measured by total viable count, TVC). Values were the mean of 3 determinations. Error bars represent 95\% CI. Color version available online.

$60 \mathrm{~nm}$ and a long tail about $259 \times 11 \mathrm{~nm})$. De Antoni et al. (2010) isolated 2 L. plantarum phages, FAGK1 and FAGK2, from kefir grains, which showed isometric capsids and long noncontractile tails with transversal striations. Briggiler Marcó et al. (2012) characterized 2 L. plantarum virulent phages, ATCC $8014-\mathrm{B} 1$ and ATCC 8014-B2, which were isolated from corn silage and anaerobic sewage sludge, and found they had long noncontractile tails and belonged to the Siphoviridae family. However, Chibani-Chennoufi et al. (2004) isolated a virulent $L$. plantarum myophage, LP65, from industrial meat fermentation, which belonged to a genus of the family Myoviridae, suggesting that lateral gene transfer may have occurred between myo- and siphophages and the L. plantarum host in the more distant past. Villion and Moineau (2009) analyzed 186 Lactobacillus phages by electron microscopy and found that 109 belonged to the Siphoviridae family, 76 to the Myoviridae family, and 1 to the Podoviridae family.

The burst size of phage P1 was $132.88 \pm 2.37$ pfu/infective center, which was significantly higher than that of most Lactobacillus virulent phages. Lu et al. (2003) reported that the average burst size for phage $\varnothing \mathrm{JL}-1$

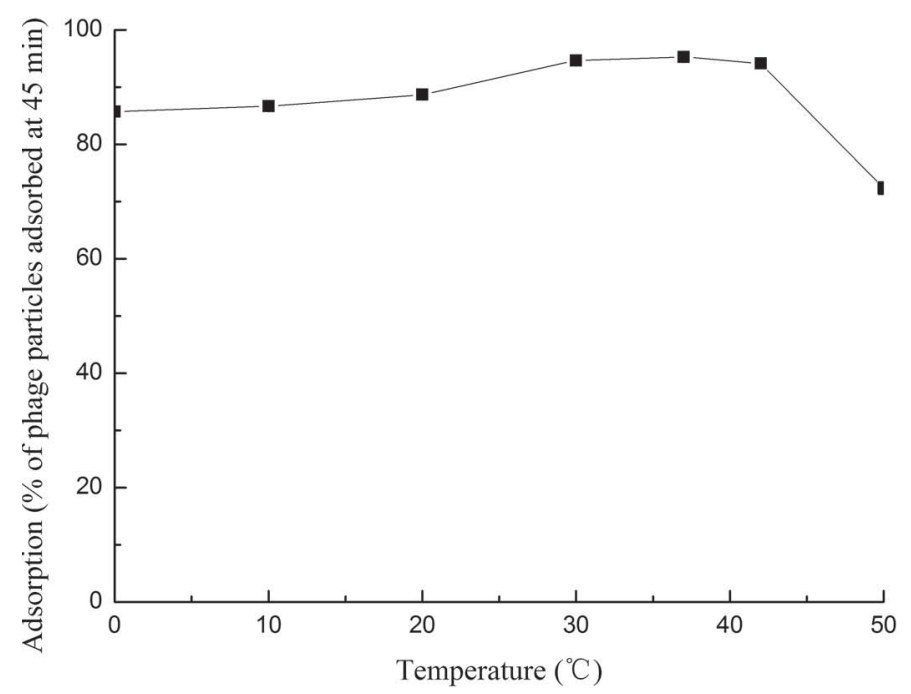

Figure 5. Influence of temperature on the adsorption (after $45 \mathrm{~min}$, in de Man, Rogosa, and Sharpe-Ca broth) of Lactobacillus plantarum phage P1. Values were the mean of 3 determinations. 


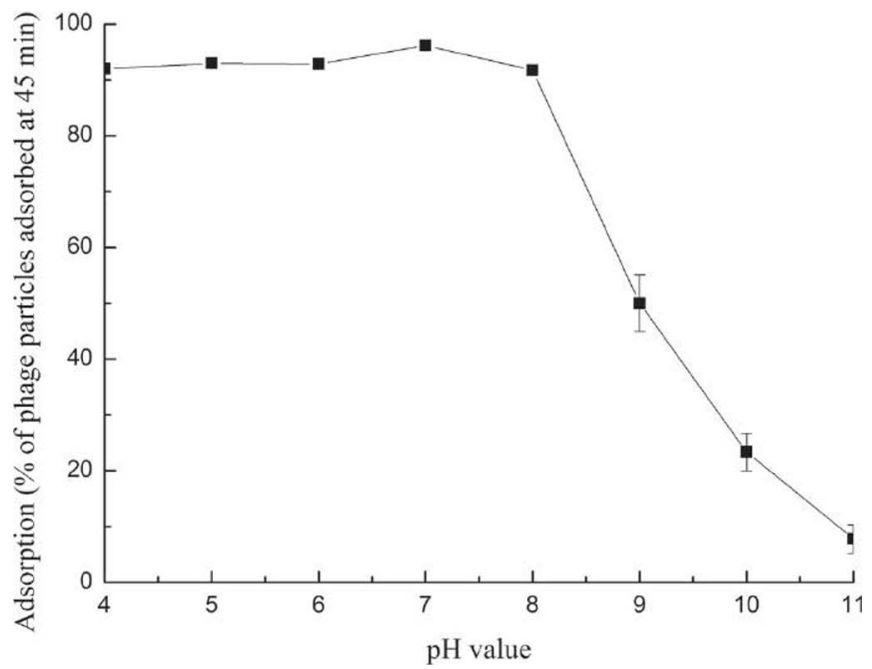

Figure 6. Influence of $\mathrm{pH}$ value on the adsorption (after $45 \mathrm{~min}$ in de Man, Rogosa, and Sharpe-Ca broth) of Lactobacillus plantarum phage P1. Values were the mean of 3 determinations. Error bars represent $95 \% \mathrm{CI}$.

at $30^{\circ} \mathrm{C}$ was $22 \mathrm{pfu} /$ infective center. Other researchers found that the burst sizes for phages FAGK1 and FAGK2 on L. plantarum ATCC 8014 at $37^{\circ} \mathrm{C}$ were 10.8 and $12 \mathrm{pfu} /$ infective center, respectively (De Antoni et al., 2010). Briggiler Marcó et al. (2010) reported burst size at $37^{\circ} \mathrm{C}$ for phages $\mathrm{B} 1$ and $\mathrm{B} 2$ on $L$. plantarum ATCC 8014 were 60 and $83 \mathrm{pfu} /$ infective center, respectively; however, Trevors et al. (1983) isolated a bacteriophage, fri, with the burst size of $200 \mathrm{pfu} /$ infective center at $30^{\circ} \mathrm{C}$ from the L. plantarum portion of a commercial meat starter culture. The effect of temperature on phage propagation could be due to temperature-dependent changes in the bacterial cell wall affecting the adsorption ability of the phages, and temperatures of 30 and $37^{\circ} \mathrm{C}$ may be more effective (Caso et al., 1995). Although temperature had little effect on the survival rate of $L$. plantarum phage P1 (Figure $3 \mathrm{a}$ ), $50^{\circ} \mathrm{C}$ significantly reduced adsorption rate on the host strain (Figure 5). Furthermore, phage P1 exhibited high infectivity at $\mathrm{pH} 6$ to 8 , a narrower range than the 4 phages (B1, B2, FAGK1, FAGK2) from $L$. plantarum ATCC 8014 (Briggiler Marcó et al. 2010). Our results also showed that this phage adsorbed effectively on L. plantarum IMAU10120 cells at $\mathrm{pH}$ ranging from 4 to 8 . Thus, optimal adsorption conditions for the phage studied herein were $\mathrm{pH}$ ranging from 6 to 8 and incubation temperatures from 30 to $42^{\circ} \mathrm{C}$. Thus, thermal treatments or changes in environmental $\mathrm{pH}$ values could be considered when designing phagecontrol strategies in fermentation processes involving the host bacteria.

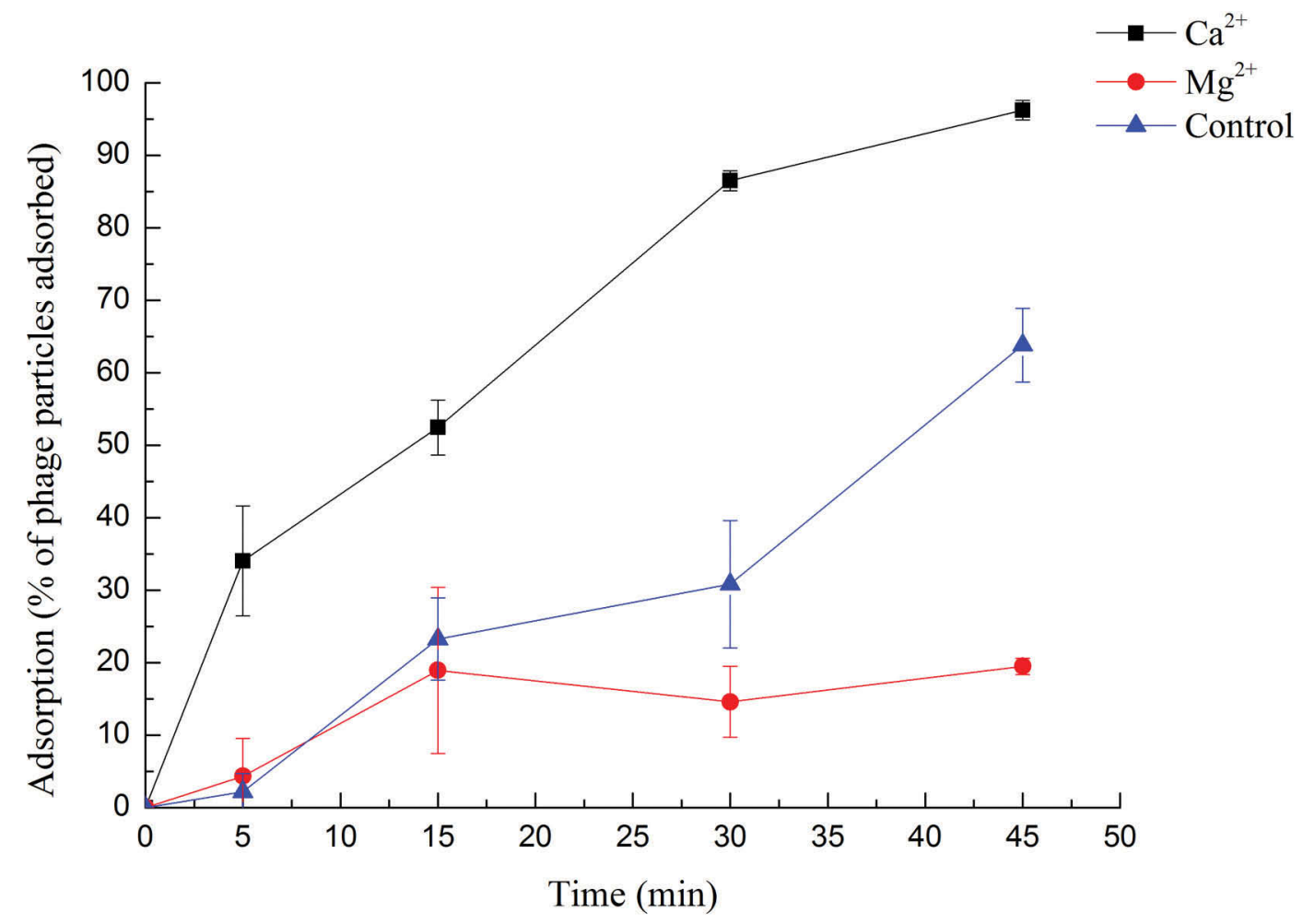

Figure 7. Influence of divalent cations on the adsorption kinetics $\left(\right.$ at $\left.37^{\circ} \mathrm{C}\right)$ of Lactobacillus plantarum phage P1. Values were the mean of 3 determinations. Error bars represent $95 \%$ CI. Color version available online. 
The addition of calcium ions significantly increased the adsorption rate of phage $\mathrm{P} 1$, and magnesium ions expressed a negative effect on its adsorption. Unlike our results, in Briggiler Marcó et al. (2010), neither $\mathrm{Ca}^{2+}$ nor $\mathrm{Mg}^{2+}$ was necessary for adsorption or to complete the lytic cycle of the 4 phages (B1, B2, FAGK1, FAGK2). $\mathrm{Lu}$ et al. (2003) reported that excess $\mathrm{Ca}^{2+}(5-30 \mathrm{mM})$ in MRS medium did not affect the adsorption rate in the first 30 min but did promote rapid phage propagation and cell lysis. Those authors also suggested that the levels of calcium or other cations in MRS medium were sufficient for the initial infection steps but not for subsequent cycles. For other lactobacilli phages, the requirement of calcium for adsorption or lysis was variable (Capra et al., 2006; Suárez et al., 2008). The addition of inhibitors of cell protein synthesis (chloramphenicol) did not affect the adsorption of phage P1, which was similar to the results of Briggiler Marcó et al. (2010). As described previously, it would not be expected that phage binding is an energy-dependent process. Based on the results obtained in our research, further studies might be needed to examine the effects of high thermal, chemical, and photocatalytic treatments on inactivation. Furthermore, more studies are needed to determine if the decrease in adsorption is related to the disorganization of phage receptor sites or to the absence of host cell energy (Briggiler Marcó et al., 2010).

\section{CONCLUSIONS}

A Lactobacillus virulent phage $\mathrm{P} 1$ belonging to the Siphoviridae family was isolated from abnormal fermented liquid of L. plantarum IMAU10120. The latent period of this phage was $45 \mathrm{~min}$, the burst time was 90 min, and the burst size was $132.88 \pm 2.37 \mathrm{pfu} /$ infective center. Temperature had little effect on phage and strain viability but a temperature of $50^{\circ} \mathrm{C}$ significantly reduced the adsorption rate of the phage. $\mathrm{pH}$ had a more obvious influence on phage viability and adsorption rate, and optimum $\mathrm{pH}$ values for phage adsorption ranged from 6 to 8 . Calcium ions promoted and increased the adsorption rate of phage $\mathrm{P} 1$ but chloramphenicol (an inhibitor of cell protein synthesis) had no effect. Further studies should focus on the high thermal, chemical, and photocatalytic resistance of this virulent phage and designing the available strategies to reduce phage infections in industrial environments.

\section{ACKNOWLEDGMENTS}

This work was supported by Natural Science Foundation of China (Beijing; Grant No. 31301517), Natural
Science Foundation of Inner Mongolia, Huhot, China (Grant No. 2013MS1207).

\section{REFERENCES}

Briggiler Marcó, M., J. E. Garneau, D. Tremblay, A. Quiberoni, and S. Moineau. 2012. Characterization of two virulent phage of Lactobacillus plantarum. Appl. Environ. Microbiol. 78:8719-8734.

Briggiler Marcó, M., J. A. Reinheimer, and A. Quiberoni. 2010. Phage adsorption to Lactobacillus plantarum: Influence of physiological and environmental factors. Int. J. Food Microbiol. 138:270-275.

Capra, M. L., A. Quiberoni, and J. Rinheimer. 2006. Phages of Lactobacillus casei/paracasei: response to environmental factors and interaction with collection and commercial strains. J. Appl. Microbiol. 100:334-342.

Caso, J. L., C. G. de los Reyes-Gavilán, M. Herrero, A. Montilla, A. Rodríguez, and J. E. Suarez. 1995. Isolation and characterization of temperate and virulent bacteriophage of Lactobacillus plantarum. J. Dairy Sci. 78:741-750.

Chibani-Chennoufi, S., M. L. Dillmann, L. Marvin-Guy, S. RamiShojaei, and H. Brüssow. 2004. Lactobacillus plantarum bacteriophage LP65: A new member of the SOP1-like genus of the family Myoviridae. J. Bacteriol. 186:7069-7083.

Costa, G. N., F. C. Marcelino-Guimaráes, G. T. Vilas-Bôas, T. Matsuo, and L. H. S. Miglioranza. 2014. Potential fate of ingested Lactobacillus plantarum and its occurrence in human feces. Appl. Environ. Microbiol. 80:1013-1019.

De Antoni, G., M. Zago, O. Vasek, G. Giraffa, D. Carminati, M. Briggiler Marcó, J. Reinheimer, and V. Suárez. 2010. Lactobacillus plantarum bacteriophages isolated from Kefir grains: Phenotypic and molecular characterization. J. Dairy Res. 77:7-12.

Emond, E., and S. Moineau. 2007. Bacteriophages and food fermentations. Pages 93-124 in Bacteriophage: Genetics and Molecular Biology. S. McGrath and D. van Sinderen, ed. Horizon Scientific Press/Caister Academic Press, Norfolk, VA.

Kodaira, K. I., M. Oki, M. Kakikawa, N. Watanabe, M. Hirakawa, K. Yamada, and A. Taketo. 1997. Genome structure of the Lactobacillus temperate phage wgle: The whole genome sequence ad the putative promoter/repressor system. Gene 187:45-53.

Lu, Z., F. Breidt, H. P. Fleming, E. Altermann, and T. R. Klaenhammer. 2003. Isolation and characterization of a Lactobacillus plantarum bacteriophage $\varnothing \mathrm{JL}-1$ from a cucumber fermentation. Int. J. Food Microbiol. 84:225-235.

Ma, C., G. Cheng, Z. Liu, G. Gong, and Z. Chen. 2016. Determination of the essential nutrients required for milk fermentation by Lactobacillus plantarum. LWT Food Sci. Technol. 65:884-889.

Müller-Merbach, M., K. Kohler, and J. Hinrichs. 2007. Environmental factors for phage-induced fermentation problems: Replication and adsorption of the Lactococcus lactis phage P008 as influenced by temperature and pH. Food Microbiol. 24:695-702.

Neviani, E., D. Carminati, and G. Giraffa. 1992. Selection of some bacteriophage-and lysozyme-resistant variants of Lactobacillus helveticus CNRZ 892. J. Dairy Sci. 75:905-913.

Quiberoni, A., V. B. Suárez, A. G. Binetti, and J. A. Reinheimer. 2011. Bacteriophage. Pages 430-438 in Encyclopedia of Dairy Science. Vol. 1. 2nd ed. J. Fuquay, P. Fox, and P. McSweeney, ed. Academic Press, Elsevier Science, Cambridge, MA.

Suárez, V., S. Moineau, J. Reinheimer, and A. Quiberoni. 2008. Angentinean Lactococcus lactis bacteriophage: Genetic characterization and adsorption studies. J. Appl. Microbiol. 104:371-379.

Trevors, K. E., R. A. Holley, and A. G. Kempton. 1983. Isolation and characterization of a Lactobacillus plantarum bacteriophage isolated from a meat starter culture. J. Appl. Bacteriol. 54:281-288.

Villion, M., and S. Moineau. 2009. Bacteriophages of lactobacillus. Front. Biosci. (Landmark Ed.) 14:1661-1683.

Yoon, B. H., S. Hwan Jang, and H. I. Chang. 2011. Sequence analysis of the Lactobacillus temperate phage Sha1. Arch. Virol. 156:16811684 . 